\title{
薄液膜下における鉄-亜鉛対のカソード防食距離の 数値解析
}

\author{
岡田 信宏* ·竹林 美樹* ・松本 雅充* · 木本 雅也* · 工藤 赳夫* \\ Numerical Analysis of Cathodic Protection Distance for Steel-Zinc Couple under Thin Layer Electrolytes \\ Nobuhiro OKada, Miki TaKebayashi, Masamitsu Matsumoto, Masanari Kımoto and Takeo Kodou
}

\begin{abstract}
Synopsis : Cathodic protection distance at the shear cut edge of zinc coated steel sheet is an important parameter for the lifetime of the steel material. However, cathodic protection distance is variable for electrolyte thickness, electric conductivity and so on. It is difficult to quantify the cathodic protection distance under various environmental conditions. So it is useful to estimate the cathodic protection distance by numerical analysis.

Most of numerical analysis models for galvanic corrosion use a polarization curve measured in a bulk electrolyte solution. However, under thin layer electrolytes, the cathodic current density strongly depends on the electrolyte thickness and the polarization curve shifts by salt concentration. So we developed the numerical analysis model that the polarization curve is calculated by the electrolyte thickness and $\mathrm{NaCl}$ concentration.

We investigated the cathodic protection distance in $\mathrm{NaCl}$ solution for several thicknesses and concentrations by numerical analysis. Moreover, we estimated the cathodic protection distance in the drying process of $\mathrm{NaCl}$ solution on the shear cut edge of zinc coated steel sheet.
\end{abstract}

Key words: Galvanic; protection distance; sacrifice distance; zinc coated steel; numerical analysis; cut edge; corrosion.

\section{1. 緒言}

亜鉛および带鉛系合金めつきを施した鋼板は,バリア効 果と犠牲防食効果による優れた耐食性があり ${ }^{1)}$, 自動車, 建材，家電の材料として広く用いられている。犠牲防食効 果は，電位の異なる金属が接触している場合に生じるガル バニック腐食による効果である。ガルバニック腐食では, 電位の卑な金属が陽極（アノード）となり，電位の貴な金 属が陰極（カソード）となる電池が形成され，陽極となっ た卑な金属の腐食が促進し，貴な金属の腐食が抑制される。 鋼板の切断面では, 初期から下地鉄が露出しているため, バリア効果は期待できず，主な防食効果は犠牲防食効果の みとなる。犠牲防食により腐食が抑制される距離は, 犠牲 防食距離, 又はカソード防食距離と呼ばれており, 鋼板寿 命を決定する重要な因子である。また，鋼板の使用環境に より犠牲防食距離を推定することが可能となれば，めっき 厚みや塗装条件の最適化を四ることも可能となる。

しかしながら，犠牲防食距離は，電解質である水溶液の 液膜厚や導電率，亜鉛部及び鉄部の幅等の様々な因子によ り大きく変化するため, 定量的に把握することが非常に困 難である。更に, 自然環境下において鋼板は, 湿潤と乾燥 を繰り返し, 液膜厚と塩濃度が変化する。よって, 使用環 境における犠牲防食距離を推定するためには, 液膜厚と塩
濃度に対する依存性を明確にする必要がある。

幾つかの暴露試験やラボ実験における鉄と亜鉛のガルバ ニック腐食は, Zhang-4)により詳しく測定され, 液膜厚が 薄く導電率が小さい程, 又は鉄部の幅が広い程, 犠牲防食 距離は短くなることが報告されている。但し，暴露試験に おける腐食環境を定量的に評価することは難しく，ラボ実 験結果との対比が常に課題となる。よって, 腐食環境によ る犠牲防食距離を定量的に評価するには，数值解析による 検討が有効であると考えられる。

腐食現象は, 多種多様な要因が重なり合う非常に複雑な 現象であるため, 他の分野に比べて数值解析による検討が 不十分な分野である。但し，ガルバニック腐食に関しては， 古くは解析的な検討 ${ }^{5-7)}$, 近年では数值解析による検 討 ${ }^{8-14)}$ が数多くなされており, 実験結果の電位との差が $0.1 \mathrm{~V}$ 以下で良く一致している場合が多い。ガルバニック 腐食の数值解析の精度は, 境界条件として用いる分極特性 に大きく依存して打り, 解析対象の実環境に近い条件下で 測定された分極特性を用いるほど実験結果と良く一致す る。言い換えれば，適切でない分極特性を数值解析に用い た場合に問題を生じる。たとえば, バルク水溶液中に打け る分極特性を用いた薄液膜厚下に抢ける数值解析結果は, 液膜厚が薄くなるほどアノード電流が低下することを示

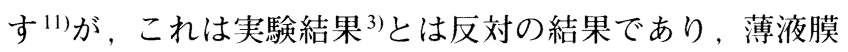


下では金属表面への酸素供給量が増加するため, カソード 電流密度がバルク水溶液中の值よりも格段に増加すること を数值解析に考慮していないことが原因である。よって， 薄液膜下における数值解析を行うには薄液膜下において測 定された分極特性を用いる必要がある。しかし，数多くの 液膜厚と塩濃度における分極測定を行うのは非常に手間で ある。

以上より, 本研究では, 液膜厚や塩濃度が変化する場合 に対応した薄液膜下におけるガルバニック腐食の数值解析 モデルを開発することを目的とした。そして，本開発モデ ルの結果を実験結果と比較し，鉄-亜鉛系におけるカソ一 ド防食距離の検討を行った。また，亜鉛めっき鋼板端面の 乾燥過程に打けるカソード防食距離の検討も行った。

\section{2. 数值解析モデル}

\section{$2 \cdot 1$ 基礎方程式}

解析対象は, Fig. 1 に示すように，幅 $W_{\text {steel }}$ の鉄と幅 $W_{\text {zinc }}$ の亜鉛対上に電解質として $\mathrm{NaCl}$ 水溶液が金属上に嬮み $t$ で 付着している2次元モデルとした。液相中の電位を $E$, 導 電率を $\sigma$ とすると，オームの法則より，電流密度べクトル iは式( 1 )となる。

$$
\mathbf{i}=-\sigma \nabla E
$$

式( 1 )の両辺の発散をとり，電流の保存則を適用すると， 式( 2 )に示すラプラス方程式となる。式(2)が，ガルバ ニック腐食の数值解析における基礎方程式である。

$$
0=-\nabla \cdot(\sigma \nabla E)
$$

式( 2 )は，有限要素法や差分法を用いて離散化することに より解が得られる ${ }^{12,13)}$ 。今回，差分法により，Fig. 2 に示 すスタガード格子を用いて離散化を行った。連立方程式の 解法は, Successive Over-Relaxation 法（SOR 法） ${ }^{15)}$ 用いた。 後述するように，境界条件となる金属表面上のアノード電 流密度は電位に依存する。よって，式(2)を解いて得られ た電位により境界条件を更新するという作業を繰り返し， 各要素における $\nabla \cdot \mathbf{i}$ の最大值が $1 \times 10^{-4}$ 以下に収束するま で反復計算を行った。

\section{$2 \cdot 2$ 分極特性のモデル化}

ガルバニック腐食の数值解析には，境界条件として金属 表面の電流密度と電位の関係である分極特性が必要であ る。分極特性は，液膜厚や塩濃度により変化するため，従 来の数值解析モデルを用いて液膜厚と塩濃度の依存性の検 討を行うには，各条件下における分極測定が必要となる。 本開発モデルでは，液膜厚と塩濃度の変化による分極特性 の変化を数学モデルから再現することにより，分極測定を 必要としないことが特徴である。以下に本モデルにおける 分極特性のモデル化の詳細を説明する。

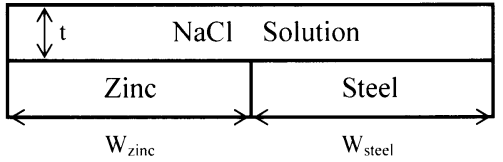

Fig. 1. Schematic diagram of the zinc-steel corrosion couple for numerical analysis.

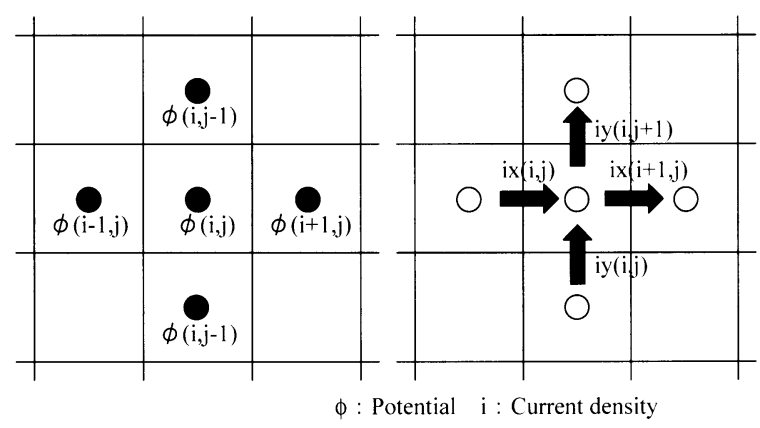

Fig. 2. Layout of the staggered grid for numerical analysis.

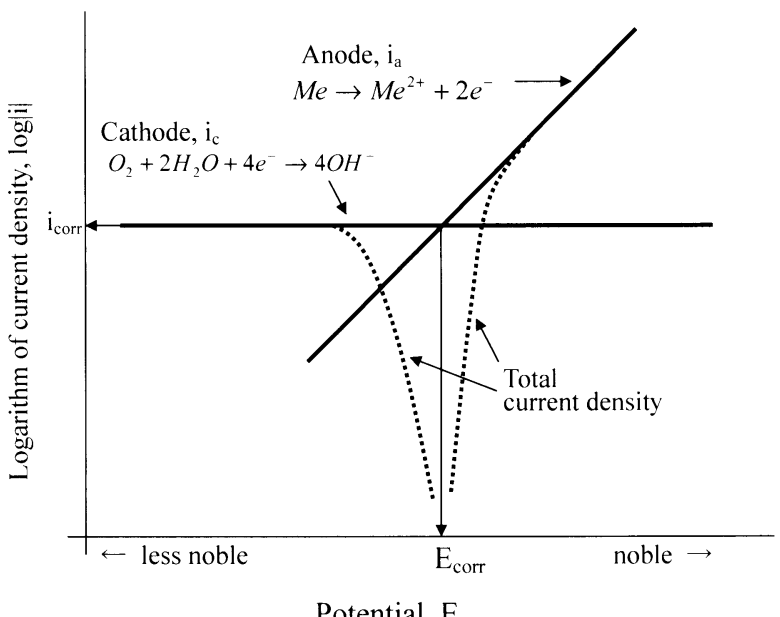

Fig. 3. Schematic representation of polarization curve.

Fig. 3 は，分極特性の模式図を示す。Fig. 3では，ある金 属 Meが 2 価の陽イオンとして溶出するアノード反応と酸 素還元によるカソード反応の電位と電流密度の関係を示し ている。カソード電流密度 $i_{c}$ は, 水素発生が無視できる中 性溶液中では電位に依存しない平坦な分布となる。アノ一 ド電流密度 $i_{a}$ は, $\log i_{a}$ が電位に対して直線的に変化する ターフェルの関係となる。分極測定から得られる電流密度 は，カソード電流密度とアノード電流密度の総和である外 部電流密度であり, Fig. 3 中に破線として示す。カソード 電流密度とアノード電流密度が等しく，外部電流密度がほ ぼ零となる電位を腐食電位 $E_{\text {corr }}$ と呼び，このときの電流密 度を腐食電流密度 $i_{\text {corr }}$ と呼ぶ。

本モデルにおけるカソード電流密度は，Fig. 4に示すよ うに，液膜厚が薄い場合は電流密度が増加し，厚い場合は 電流密度が低下する，カソード特性のモデル化について以 下に説明する。

カソード電流密度は, 式( 3 )に表される酸素還元反応に 


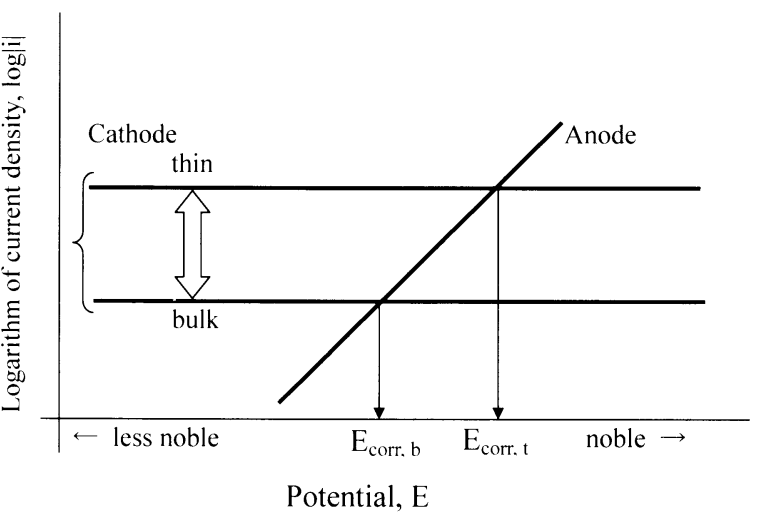

Fig. 4. Schematic representation of cathodic current density model.
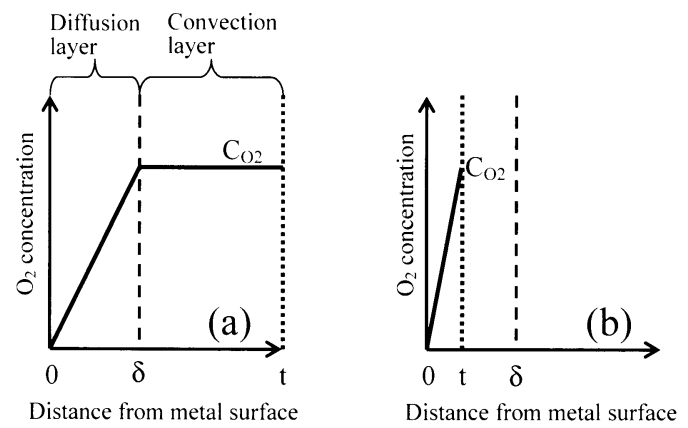

Fig. 5. Schematic representation of dissolved $\mathrm{O}_{2}$ concentration distribution in (a) a bulk solution and (b) a thin electrolyte film.

よる電子授受により表される。

$\mathrm{O}_{2}+2 \mathrm{H}_{2} \mathrm{O}+4 \mathrm{e}^{-} \Rightarrow 4 \mathrm{OH}^{-}$

Fig. 5は, (a)バルク水溶液中と (b) 薄液膜下における溶解酸 素濃度分布の模式罒を示す。バルク水溶液中では, 金属表 面近くに濃度勾配を持つ拡散層が形成され，その沖合に濃 度が一定とみなせる対流層がある。対流層中の酸素解度を $C_{\mathrm{O}}$, とし, 拡散層厚みを $\delta$, 水溶液中の酸素拡散係数を $D$, ファラデー定数を $F$ とすると, バルク水溶液中のカソード 電流密度 $i_{c}$ は式 $(4)$ として与えられる。

$$
i_{c}=\frac{4 F D C_{\mathrm{O}_{2}}}{\delta}
$$

ここで, 平板上の静止水溶液の拡散層厚みは, $0.1 \sim 0.5 \mathrm{~mm}$ 程度と言われており, 今回は $\delta=0.5 \mathrm{~mm}$ とした。但し, 液 膜厚が拡散層厚み以下となる薄液膜の場合は，対流層が存 在せず，表面までが拡散層となる。よって，式(5)の拡散 層厚み $\delta$ は液膜厚 $t$ に置き換えられ, 液膜厚が薄くなるほ ど濃度勾配が大きくなり，カソード電流密度が増加する。

また, 液膜厚 $0.01 \mathrm{~mm}$ 以下の領域では, 拡散よりも水溶 液表面における酸素溶解速度が律速となる ${ }^{16)}$ 。しかしなが ら，酸素溶解速度の $\mathrm{NaCl}$ 濃度依存性が明らかではないた め, 今回の数值解析モデルでは, 液膜厚 $0.01 \mathrm{~mm}$ 以下のカ

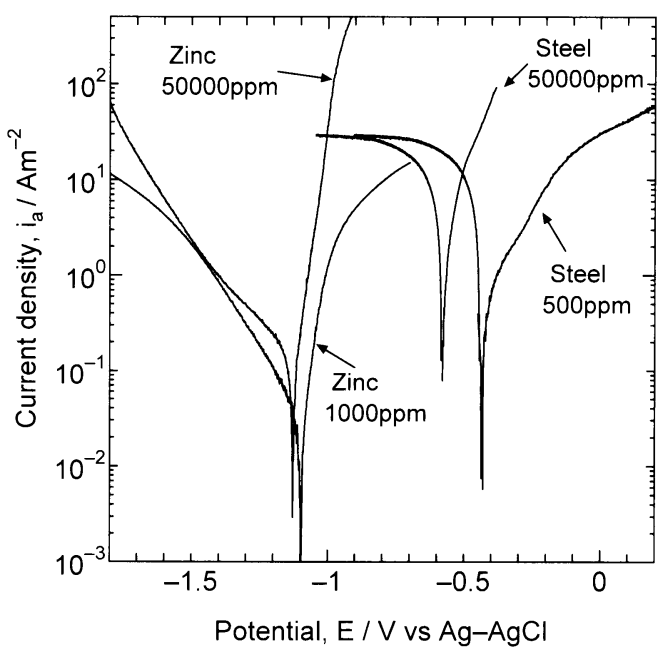

Fig. 6. Polarization curves of steel and zinc in $\mathrm{NaCl}$ solution.

ソード電流密度は，0.01 mmにおける值から增加せずに一 定とした。

次にアノード特性のモデル化について説明する。アノー ド電流密度は, 式( 5 )に示すターフェルの関係として表し た。ここで， $\alpha$ はターフェル定数, $n$ は価数，Rは気体定 数, $T$ は温度である。亜鉛と鉄の価数は共に 2 であり, ターフェル定数は, $\mathrm{NaCl}$ 濃度 $50000 \mathrm{ppm} に お け る$ 分極測定 結果と本モデルの計算による分極曲線が一致するように調 整し，それぞれ $\alpha_{\text {zinc }}=1.2 ， \alpha_{\text {steel }}=0.38$ とした。

$$
i_{a}=i_{\text {corr }} \exp \left\{\left(E-E_{\text {corr }}\right) \frac{\alpha n F}{R T}\right\}
$$

Fig. 6は，いくつかの $\mathrm{NaCl}$ 濃度における鉄と带鉛の分極 曲線を示す。Fig. 6より, $\mathrm{NaCl}$ 濃度 $50000 \mathrm{ppm}$ の場合には, 鉄，亜鉛共にアノード電流密度はターフェルの関係に近い 分布を示している。しかし, $\mathrm{NaCl}$ 濃度が低下すると, 分 極曲線が貴側にシフトし， $10 \mathrm{~A} / \mathrm{m}^{2}$ 程度以上の高電流密度 域ではアノード電流密度がターフェルの関係よりも低い值 を示している。これらの現象は，低 $\mathrm{NaCl}$ 濃度の場合には 金属表面に不動態膜が形成されやすいために，アノード活 性な表面積が減少することが原因と考えられている ${ }^{17}$ 。ま た, Fig. 6における带鉛のカソード分極曲線にはFig. 3に示 すような平坦な領域がない。これは, 水の電気分解の平衡 電位 $(-1.45 \mathrm{~V} v \mathrm{~s} . \mathrm{Ag}-\mathrm{AgCl})$ よりも電位が低い領域では, 水 素発生反応が生じていることが原因である。鉄一冓鉛対に おいては，亜鉛がカソードサイトにならないので，今回の 数值解析では水素発生反応は考慮していない。

今回，不動態膜によるアノード電流密度の低下を理論的 にモデル化することが困難であったので，ターフェル勾配 は一定とし, 電位のシフト量は $\mathrm{NaCl}$ 活量に依存するとし た単純なモデル化を行った。よって，本モデルでは，低 


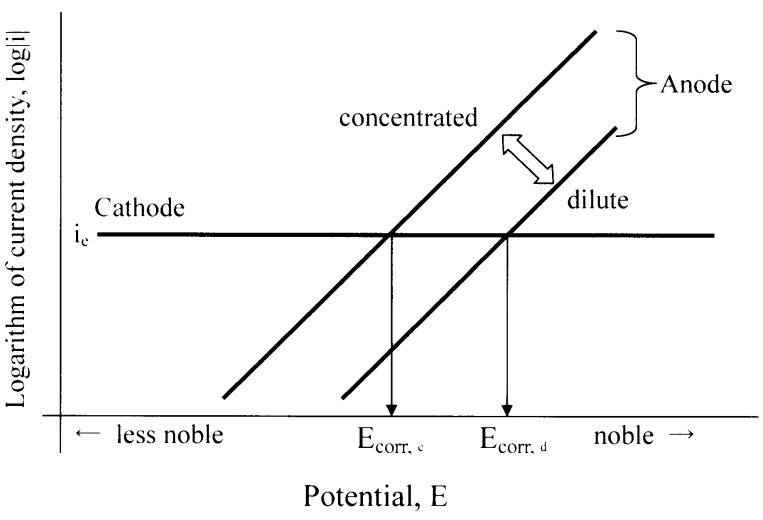

Fig. 7. Schematic representation of anodic current density model.

$\mathrm{NaCl}$ 濃度におけるアノード電流密度を過大に評価すると いう点を留意する必要がある。

電位のシフトを考慮したアノード特性モデルの模式図を Fig. 7に示す。式( 5 )より，勾配を一定とすると，腐食電 位が決まればアノード特性を表現することができる。腐食 電位と $\mathrm{NaCl}$ 濃度の関係は, 実測結果から求めた近似式を 用いた。腐食電位と活量補正した $\mathrm{NaCl}$ 濃度の関係を Fig. 8 に示す。ここで, $\gamma_{ \pm}$は重量モル濃度 $m(\mathrm{~mol} / \mathrm{kg})$ での平均活 量係数であり，式( 6 )から求めた ${ }^{17)}$ 。式( 6 )中の $\lambda$ は電解 質による定数であり, $\mathrm{NaCl}$ の場合は $\lambda=0.130$ である ${ }^{18)}$

$$
\log \gamma=-0.5115 \sqrt{m} /(1+\sqrt{m})+\lambda m
$$

Fig. 8から式(7), (8)に示す近似式を作成し，この腐食電位 を式(5)に代入することによりアノード電流密度の $\mathrm{NaCl}$ 濃 度依存性を表現した。

$$
\begin{aligned}
& E_{\text {corr, stecl }}=0.0979 \log \left(\gamma_{ \pm} m_{\mathrm{NaCl}}\right)-0.6109 \\
& E_{\text {corr,zinc }}=0.03711 \log \left(\gamma_{ \pm} m_{\mathrm{NaCl}}\right)-1.0228
\end{aligned}
$$

\section{$2 \cdot 3$ その他 $\mathrm{NaCl}$ 濃度の影響}

腐食現象に関わるパラメータは数多くあり，その全てを 数值解析に考慮することは不可能である。今回は $\mathrm{NaCl}$ 濃 度の影響に着目したモデル化を行ない，上述した分極特性 の他に導電率と酸素溶解度の影響を考虑した。

\section{(1) $\mathrm{NaCl}$ 水溶液の導電率}

$\mathrm{NaCl}$ の容量モル濃度 $c(\mathrm{~mol} / \mathrm{L})$ が $0.3 \mathrm{~mol} / \mathrm{L}$ 以下の場合に は，モル導電率 $\Lambda$ は式( 9 )の実験式 ${ }^{19)}$ で表される。

$$
(\Lambda+59.78 \sqrt{c}) /(1-0.2273 \sqrt{c})=126.45+95.79 c-65.29 c^{2}
$$

ここで, 導電率 $\sigma$ とモル導電率 $\Lambda\left(\mathrm{S} \mathrm{cm}^{2} / \mathrm{mol}\right)$ との関係は, $\sigma=1000 \Lambda c(\mathrm{~S} / \mathrm{m})$ である。 $\mathrm{NaCl}$ のモル濃度が $0.3 \mathrm{~mol} / \mathrm{L}$ 以上 の場合の導電率は, 飽和に近い $\mathrm{NaCl}$ 濃度 $(3.42 \mathrm{~mol} / \mathrm{L})$ にお ける導電率 $19.87 \mathrm{~S} / \mathrm{m}$ との線形補間により求めた。

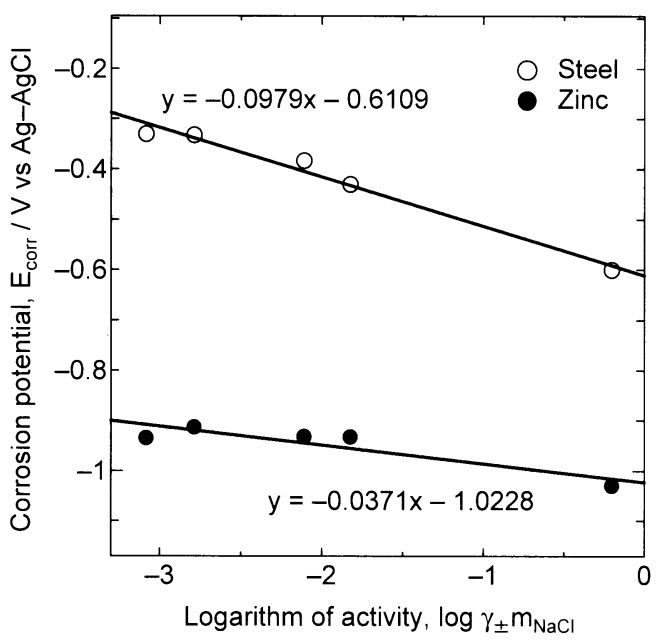

Fig. 8. Corrosion potential of steel and zinc dependence on $\mathrm{NaCl}$ activity.

(2) 酸素溶解度

温度 $T(\mathrm{~K})$ における酸素の純水への溶解度は, 文献 ${ }^{20)}$ り温度 $T$ の関数として, 式(10)に示す近似式を用いた。

$$
\mathrm{CO}_{2}(T)=8.18 \times 10^{-2} \exp \left(-1.92 \times 10^{-2} T\right)
$$

更に, Salting-out効果により，塩濃度が増せば酸素溶解度 は減少し，式(11)に示す実験式で表現される21)。

$\mathrm{CO}_{2}(T, c)=\mathrm{CO}_{2}(T) \cdot 10^{-k_{*} \cdot c}$

ここで， $k_{s}$ は電解質に依存する係数であり, $\mathrm{NaCl}$ の場合は $k_{\mathrm{s}}=0.139^{21)}$ である。

(3) 酸素拡散係数

酸素拡散係数も電解質濃度により変化する ${ }^{22}$ が, $\mathrm{NaCl}$ 濃度依存性は明らかではない。本モデルでは, 定数として $D=1.9 \times 10^{-9} \mathrm{~m} / \mathrm{s}^{22)}$ を用いた。

\section{$2 \cdot 4$ 分極曲線}

従来の数值解析モデルでは実測值による分極曲線を境界 条件として用いるが，本モデルでは上述した分極特性モデ ルから算出した分極曲線を境界条件として用いる。金属表 面の電流密度 $i$ は, 金属から溶液に向かう電流を正とする と, アノード電流密度 $i_{a}$ とカソード電流密度 $i_{c}$ の差 $i=i_{a}-i_{c}$ として分極曲線が表現できる。

本モデルによる分極曲線の計算例として， $\mathrm{NaCl}$ 濃度 $50000 \mathrm{ppm}$ と $50 \mathrm{ppm}$, 液膜厚 $1 \mathrm{~mm}$ と $0.01 \mathrm{~mm}$ における分極 曲線を Fig. 9に示す。Fig. 9には, $\mathrm{NaCl}$ 濃度 50000 ppmのバ ルク水溶液中で測定した分極曲線も比較のために示してい る。実測の分極曲線は，回転子による覮找と空気バブリン グという条件で測定を行った。実測の分極曲線の限界電流 密度は，強制対流により酸素が十分に供給されるため，静 止水溶液を仮定している計算例の液膜厚 $0.01 \mathrm{~mm}$ の限界電 流よりも大きな值を示している。

Fig. 9の計算例で $\mathrm{NaCl}$ 濃度 50000 ppm-液膜厚 $1 \mathrm{~mm}$ を基 


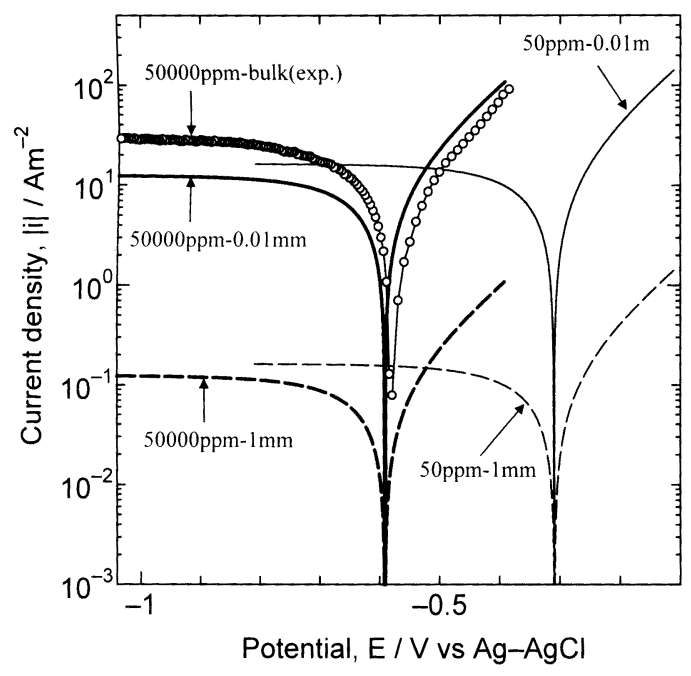

Fig. 9. Polarization curves represented by mathematical model.

準とすると，薄液膜化した $50000 \mathrm{ppm}-0.01$ mmの場合は， カソード電流密度が増加するために, 高電流密度側にシフ トしている。低 $\mathrm{NaCl}$ 濃度化した $50 \mathrm{ppm}-1 \mathrm{~mm}$ の場合は， 腐食電位が貴側にシフトし，且つ Salting-out効果により， カソード電流密度が若干增加している。Fig. 9に示すよう に, 本モデルでは, 薄液膜化によるカソード電流密度の増 加や $\mathrm{NaCl}$ 濃度による電位のシフトを表現できている。し かしながら，本モデルには考虑されていない現象が幾つか ある。考虑されていない現象として，水素発生反応やFig. 6で確認される $\mathrm{NaCl}$ 濃度によるアノード電流密度の勾配変 化が挙げられる。これらの現象を数值解析モデルに組み込 み，精度を向上していくことが今後の課題である。

\section{3. 実験および数值解析の結果と考察}

\section{$3 \cdot 1$ 電位分布の比較}

本数值解析モデルは，前節で述べたモデルから算出した 分極特性を用いるため，実測した分極特性を用いた従来モ デルほどの計算精度は期待できない。本モデルによる計算 結果と実測值との差を確認するために, $\mathrm{NaCl}$ 濃度と液膜 厚を变化させた場合の鉄一帚鉛対上の電位測定を行い，数 值解析結果との比較を行った。今回, 電流密度分布につい ては測定しておらず, 電流密度分布の比較は行っていな い。

薄液膜下に打ける電位測定方法は文献 ${ }^{23)}$ を参考とし，実 験方法の模式図を Fig.10に示す。試験片は，冷延鋼板に電 気覀鉛めっき $\left(20 \mathrm{~g} / \mathrm{m}^{2}\right)$ を施し，鉄と亜鉛の幅をそれぞれ $25 \mathrm{~mm}$ とした。 $\mathrm{NaCl}$ 水溶液膜厚は $0.7 \sim 2 \mathrm{~mm}$ として, 金属 表面から高さ $0.5 \mathrm{~mm}$ の位置に参照電極を設置し，参照電 極を $0.1 \mathrm{~mm} / \mathrm{s}$ の速度で走査して電位測定を行った。測定環 境は温度 $35^{\circ} \mathrm{C}$, 湿度 $80 \sim 90 \%$ とし, 試験片の浸漬直後の 測定は電位の乱れが大きかったため, 浸漬後 $100 \mathrm{~s}$ に電位

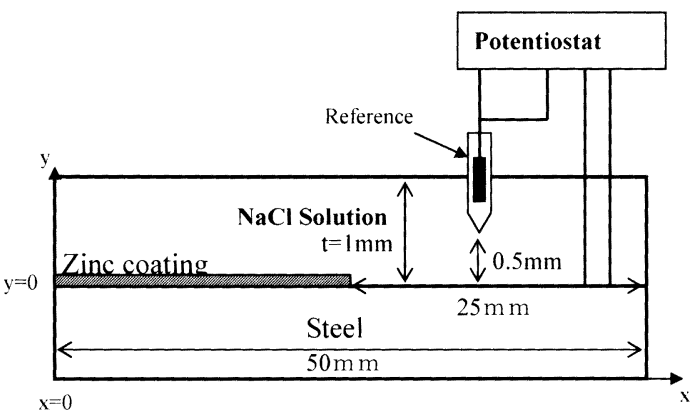

Fig. 10. Schematic representation of the potential distribution measurement on the zinc coated steel in $\mathrm{NaCl}$ solution.

測定を行った。

2章に述べた本数值解析モデルによる計算結果と実験結 果の電位分布の比較を Fig.11に示す。Fig.11は, NaCl濃度 $100 \mathrm{ppm}, 1000 \mathrm{ppm}, 10000 \mathrm{ppm}$ の場合と液膜厚 $0.7 \mathrm{~mm}$ と $2 \mathrm{~mm}$ の場合の比較を示す。Fig.11より, 数值解析結果と実 験結果の電位差は最大 $0.1 \mathrm{~V}$ 程度であり, ある程度一致し ている。 $\mathrm{NaCl}$ 濃度が高濃度, 又は液膜厚が厚い場合に電 位勾配が小さくなるという傾向も数值解析結果は実験結果 と定性的に一致している。但し, $\mathrm{NaCl}$ 濃度が $10000 \mathrm{pm}$ の 場合には実験結果と数値結果が比較的良く一致している が，1000 ppmや $100 \mathrm{ppm}$ の低 $\mathrm{NaCl}$ 濃度の場合に差が大き くなり，数值解析結果の電位勾配が実験結果よりも大き is。

低 $\mathrm{NaCl}$ 濃度における数值解析結果と実験結果の差の原 因として，分極特性の精度が挙げられるが，その他の原因 として実駼結果の電位分布が経時変化していることが考え られる。Fig.12は, $\mathrm{NaCl}$ 濃度 $100 \mathrm{ppm}$ 水溶液に浸漬後 $100 \mathrm{~s}$ と $1000 \mathrm{~s}$ における電位分布の測定結果を示す。Fig.12より， 浸漬後に時間が経過すると電位勾配が小さくなっており， 浸漬直後においては数值解析結果にもう少し近い分布であ ることが推測される。この原因として，亜鉛イオンの溶出 により導電率が増加していることが考えられる。曲鉛一鉄 界面付近の亜鉛イオン濃度は $0.005 \mathrm{~mol} / \mathrm{L}$ 程度 ${ }^{24}$ である。 参考として $0.005 \mathrm{~mol} / \mathrm{L}$ の $\mathrm{ZnSO}_{4}$ 水溶液の導電率は 0.0223 $\mathrm{S} / \mathrm{m}$ であり, $100 \mathrm{ppm}$ の $\mathrm{NaCl}$ 水溶液の導電率 $0.0113 \mathrm{~S} / \mathrm{m}$ の 倍程度である。 $\mathrm{NaCl}$ 濃度が薄い程，亜鉛イオンの溶出に よる導電率増加の影響が大きいと考えられる。

以上より，本数值解析モデルから得られた電位分布は実 験結果と比べ，高 $\mathrm{NaCl}$ 濃度については比較的良く一致す るが，低 $\mathrm{NaCl}$ 濃度の場合に $0.1 \mathrm{~V}$ 程度の差があることが確 認された。また，低 $\mathrm{NaCl}$ 濃度では，金属イオン溶出によ る導電率の增加の影響が大きいと考えられ，数值解析結果 の電位分布はこの影響のない浸漬直後の結果に相当すると 考えられる。今回，カソード防食距離の評価が目的であり， その距離は導電率が最も小さい浸漬直後に最小となると考 えられるため, 本数值解析結果により評価しても問題がな 


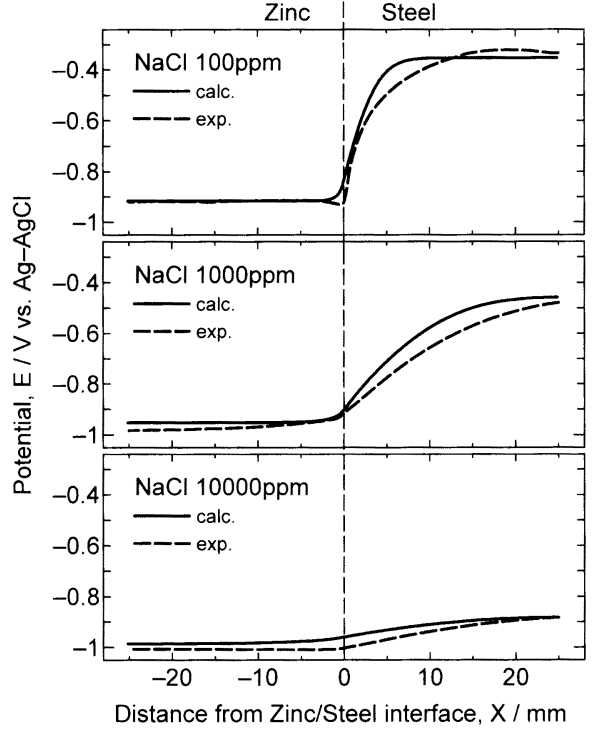

(a) $\mathrm{t}=0.7 \mathrm{~mm}$

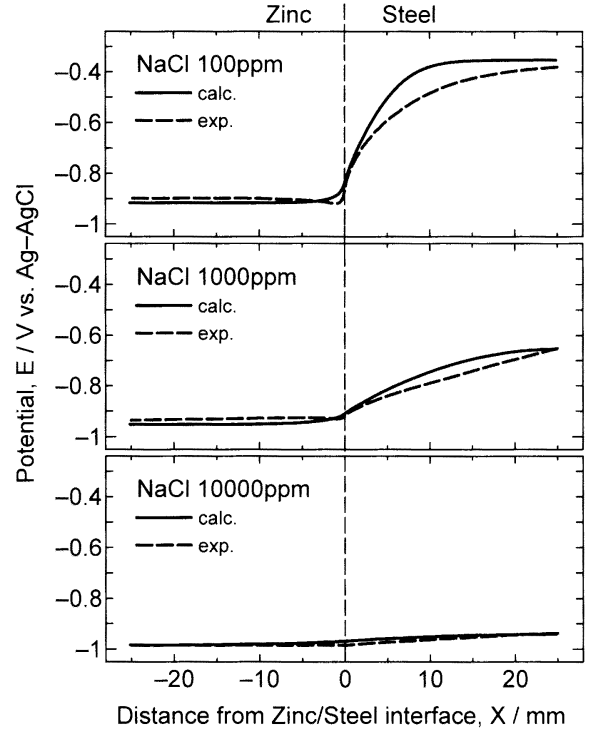

(b) $\mathrm{t}=2.0 \mathrm{~mm}$

Fig. 11. Comparison of the calculated potential distribution and the measured potential distribution in $100 \mathrm{ppm}, 1000 \mathrm{ppm}$ and $10000 \mathrm{ppm} \mathrm{NaCl}$ solution.

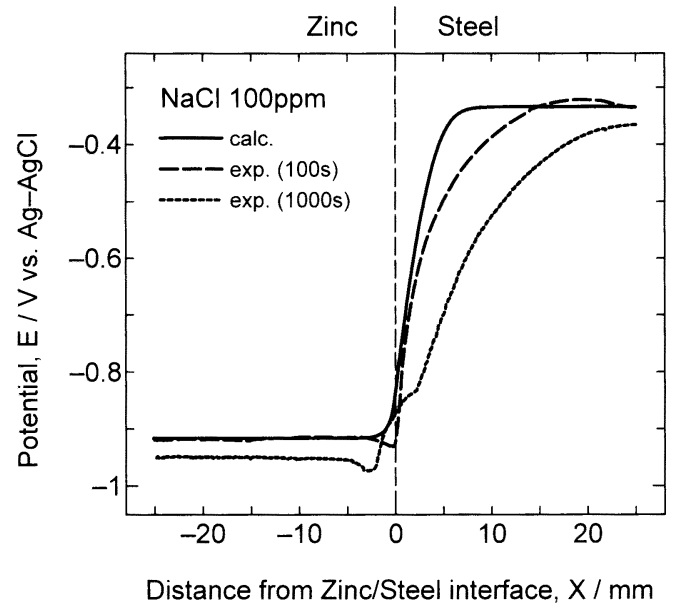

Fig. 12. Measured potential distributions at $100 \mathrm{~s}$ and $1000 \mathrm{~s}$ after the specimen immersed in $100 \mathrm{ppm}$ $\mathrm{NaCl}$ solution $(t=0.7 \mathrm{~mm})$.

いと考えられる。

\section{$3 \cdot 2$ カソード防食距離の比較}

一般的に腐食電位以下の領域がカソード防食距離と言わ れているが，㛜密に定義されている訳ではなく，数值解析 結果からのカソード防食距離を定義する必要がある。力 ソード防食距離を定義するならば，電位よりも腐食速度に 直結する金属表面上のアノード電流密度から定義すること が望ましいと考えられる。

本モデルでは，従来モデルのようにアノード電流密度と カソード電流密度の総和である外部分極曲線を用いるので はなく，アノード電流密度とカソード電流密度を区別した モデル化を行っているため, カソードサイトとなる鉄側の アノ一ド電流密度も知ることが出来る。Fig.13に液膜厚 $0.7 \mathrm{~mm}$ の数值解析結果である(a) 電位分布と(b)アノード電

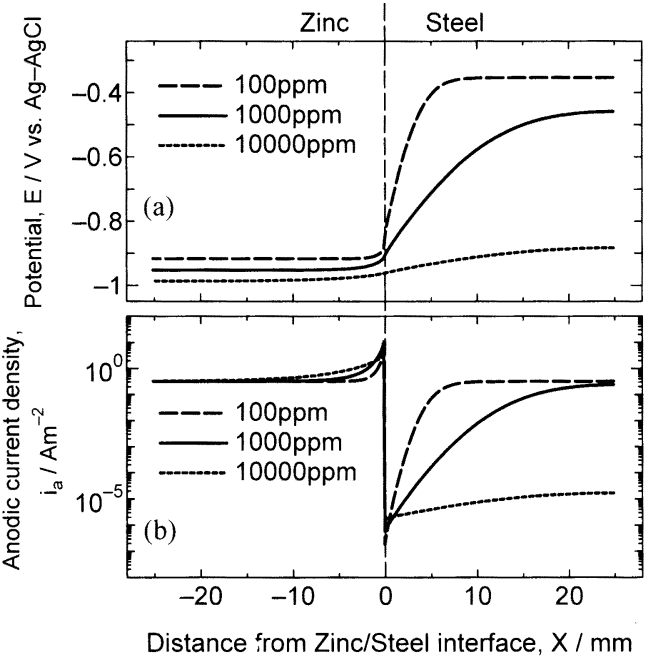

Fig. 13. (a) The potential distributions and (b) the anodic current density distributions of numerical analysis result in $100 \mathrm{ppm}, 1000 \mathrm{ppm}$ and $10000 \mathrm{ppm}$ $\mathrm{NaCl}$ solution $(t=0.7 \mathrm{~mm})$

流密度分布を示す。Fig.13の電位分布は金属表面から $0.5 \mathrm{~mm}$ の位置の值を示し，アノード電流密度は金属表面 上における值を示す。

Fig.13(b)のアノード電流密度分布より，鉄から離れた位 置の亜鉛部のアノード電流密度は一定值を示しているが， 鉄と亜鉛の界面に近づくと増加しており，界面付近の亜鉛 の腐食が促進されている。界面付近の鉄側のアノード電流 密度は非常に小さい值を示しており，界面付近の鉄が防食 されていることを意味する。 $\mathrm{NaCl}$ 濃度が $10000 \mathrm{ppm}$ の場合 には，界面から $25 \mathrm{~mm}$ の位置まで鉄側のアノード電流密度 が殆ど増加せず，鉄部 $25 \mathrm{~mm}$ の全てが防食されている。一 方， $\mathrm{NaCl}$ 濃度 $100 \mathrm{ppm}$ の場合では，界面から $5 \mathrm{~mm}$ 程度離 
れるとアノード電流密度が増加し，一定值を示している。 このアノード電流密度が一定值を示している領域は，犠牲 防食効果がなく，カソード電流密度とアノード電流密度が 等しい平衡領域である。今回，この平衡領域における平衡 電流密度の $1 / 10$ 以下のアノード電流密度となる領域を防食 距離PD (Protection Distance) と定義し，1.1倍以上の領域を 犠牲距離 SD (Sacrifice Distance) として定義した。

Fig.14(a)は，実験から確認された防食距離の写真を示す。 Fig.14(a)では，亜鉛と鉄の界面付近に赤錆が発生し，界面 付近で赤錆の侵食が留めら机ている様子を示す。赤錆の侵 食が界面と平行して留められていることから，これは犠牲 防食効果によるものであると考えられ，その距離は $4.6 \mathrm{~mm}$ である。Fig.14(a)の条件は， $\mathrm{NaCl}$ 濃度 $50 \mathrm{ppm}$ ，液 膜厚 $1.0 \mathrm{~mm}$ であり, 同条件における数值解析結果の電位 分布とアノード電流密度分布を Fig.14(b), (c)に示す。上述 した定義より，Fig.14(c)のアノード電流密度から求めた防 食距離は $3.6 \mathrm{~mm}$ であり，儀牲距離は $2.9 \mathrm{~mm}$ である。数值 解析より求めた防食距離は，実験から確認された防食距離 よりも若干短くなった。

\section{$3 \cdot 3$ 数值解析による犠牲防食距離の $\mathrm{NaCl}$ 濃度と液膜厚 依存性}

本数值解析モデルを用いて, 液膜厚と $\mathrm{NaCl}$ 濃度を変化 させた場合の検討を行った。 $\mathrm{NaCl}$ 水溶液膜厚は 10,50 , $100,250,500,1000 \mu \mathrm{m}$ の 6 通りとし，各液膜厚に打いて濃 度を $50,100,250,500,1000,2500,5000,10000,25000$ ， $50000 \mathrm{ppm}$ とした場合の計 60 通りの計算を行った。

これらの計算結果として，Fig.15に(a)防食距離と(b)犠 牲距離の $\mathrm{NaCl}$ 濃度と液膜厚に対する依存性を示す。数值 解析を行った鉄の幅が $25 \mathrm{~mm}$ なので，Fig.15における防食 距離と犠牲距離は $25 \mathrm{~mm}$ が上限值となっている。Fig.15(a) より，防食距離は，液膜厚が薄く $\mathrm{NaCl}$ 濃度が低いほど短 くなり，液膜厚が厚く $\mathrm{NaCl}$ 濃度が高いほど長くなる。 Fig. 15(b)より，犠牲距離も防食距離と同一傾向を示し，そ の距離は防食距離の $1 / 2$ 程度である。

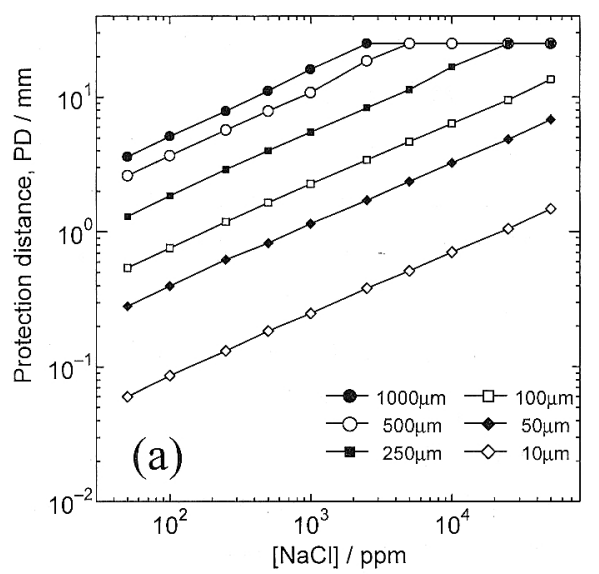

\section{4 数値解析による亜鉛めつき鋼板端面の犠牲防食距離}

前節に述べたように，防食距離は，水溶液膜厚と $\mathrm{NaCl}$ 濃度により大きく変化し，長い場合には $25 \mathrm{~mm}$ 以上となる。 ここで，我々が知りたいのは実環境に打ける带鉛めっき鋼 板端面の防食距離であり，亜鉛めっき鋼板端面上に付着し た雨水が乾燥していく過程を模擬した計算を行った。

雨水は $\mathrm{NaCl}$ 濃度 $50 \mathrm{ppm}$ に相当するとし, 初期液膜厚 $t_{0}=1 \mathrm{~mm}$ で鋼板端面に付着すると仮定した。液膜厚が溜く なるにつれ，液膜厚が減少した分だけ $\mathrm{NaCl}$ 濃度を増加さ せて，0.005 mmの液膜厚までの計算を行った。ここで， 液膜厚 $t(\mathrm{~mm})$ と $\mathrm{NaCl}$ 濃度 $C(\mathrm{ppm})$ の関倸は， $C=50 / t$ とした。

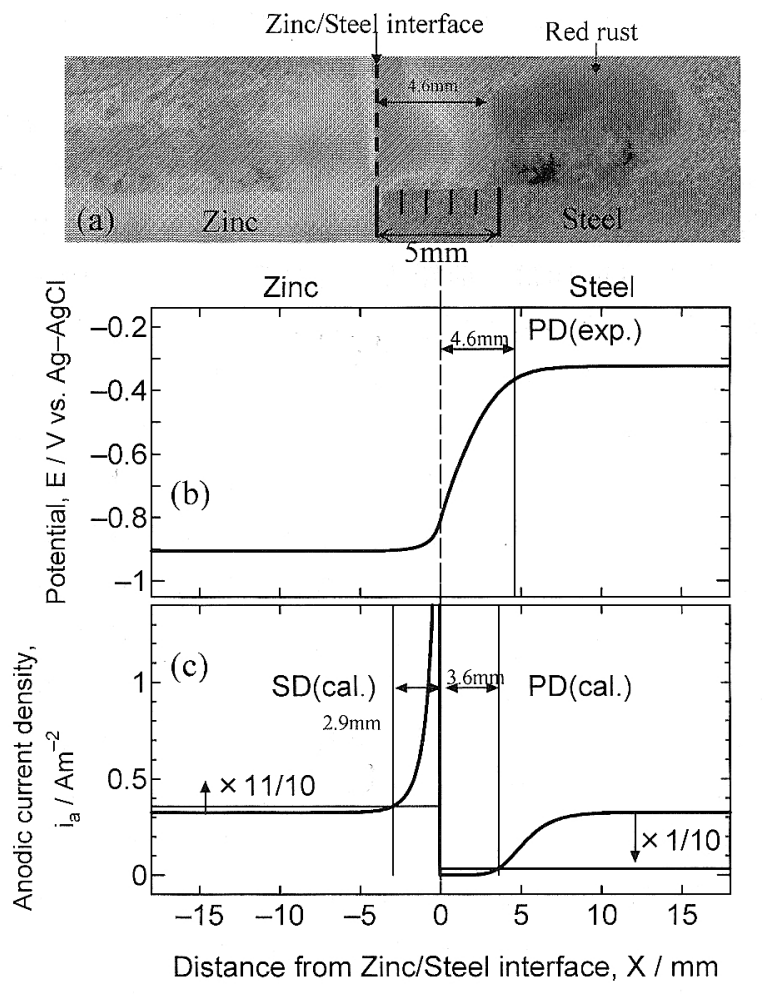

Fig. 14. (a)Picture of the protection distance in $50 \mathrm{ppm}$ $\mathrm{NaCl}$ solution. (b)Potential distribution. (c)Definition of the protection distance and the sacrifice distance decided from the anode current density distribution.

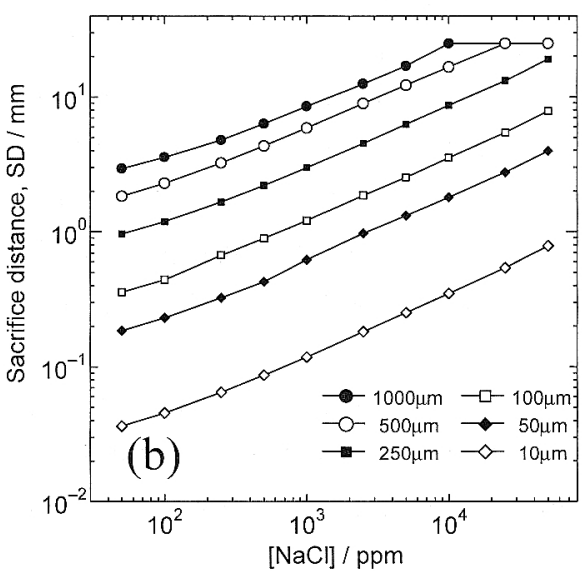

Fig. 15. Computed result of (a) the protection distance and (b) the sacrifice distance. 


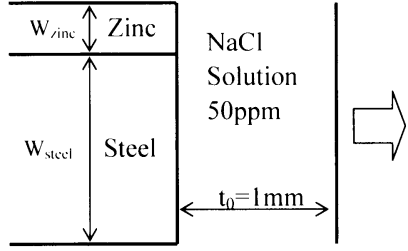

(a)Initial

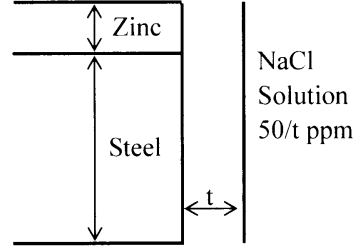

(b)Drying
Fig. 16. Schematic representation of the calculation model for drying process.

この計算モデルの模式図を Fig.16に示す。亜鉛めつき鋼板 は、鉄部厚みを $1 \mathrm{~mm}$ に固定して亜鉛めっき厚みを $10 \sim 80 \mu \mathrm{m}$ に変化した場合と，亜鉛めっき厚みを $20 \mu \mathrm{m} に$ 固定して鉄部厚みを $0.1 \sim 1.5 \mathrm{~mm}$ に変化した場合の計算を 行った。

これらの数值解析結果として, 各液膜厚における防食距 離と亜鉛腐食速度の值を Fig.17, 18に示す。Fig.17は，鉄部 の厚みを $1 \mathrm{~mm} に$ 固定して亜鉛めっき厚みを変化させた場 合であり，Fig.18は，带鉛めっき厚みを $20 \mu \mathrm{m}$ に固定して 鉄部の厚み変化させた場合である。

Fig.17(a)より，鉄部の厚みを固定した場合には，帚鉛 めっき厚みによる防食距離の変化は殆どない。但し， Fig.17(b)より，亜鉛めっき部の腐食速度は，亜鉛めっき厚 みにより大きく変化し，めっき厚みが厚いほど腐食速度が 遅くなっている。また，防食距離は液膜厚が $0.05 \mathrm{~mm}$ 以上 では鉄部 $1 \mathrm{~mm}$ の全てが防食されているが，液膜厚が 0.05 $\mathrm{mm}$ 以下となると防食距離は減少していき, 液膜厚 $0.005 \mathrm{~mm}$ の防食距離が最小の $0.52 \mathrm{~mm}$ となる。更に薄液膜 下の防食距離の検討を行いたいが, 本モデルは電流保存則 を基礎としたマクロな解析モデルであり, 分子レベルの現 象が支配的となってくる $0.001 \mathrm{~mm}$ 以下の解析には不適切 である。よって，Fig.17(a)の外挿から液膜厚が零における 防食距離を推定すると $0.48 \mathrm{~mm}$ 程度であり，曹鉛めっき鋼 板の実環境における防食距離は $0.48 \mathrm{~mm}$ 程度であると考え られる。この結果は，暴露実験結果である $1 \mathrm{~mm}$ 弱という

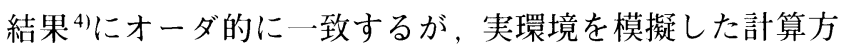
法は今後も検討していく必要がある。

亜鉛めっき厚みを固定した場合は，Fig.18(a)より，鉄部 厚み $0.5 \mathrm{~mm}$ 以下では 1 0.005 mmの液膜厚において全領域 が防食されているが，鉄部厚み $1 \mathrm{~mm}$ 以上では液膜厚が薄 くなるに従い防食距離が減少し, 鉄部厚みを固定した場合 と同様に, 液膜厚が $0.005 \mathrm{~mm}$ の防食距離は $0.52 \mathrm{~mm}$ となる。 Fig.18(b)より, 亜鉛めっきの腐食速度は, 鉄部厚みが厚い ほど腐食速度が大きくなっている。

以上より, 防食距離は亜鉛めっき厚みと鉄部厚みには依 存せず，液膜厚と $\mathrm{NaCl}$ 濃度にのみ依存している結果と なった。但し，亜鉛めっきの腐食速度は，亜鉛めっき厚み 又は鉄部厚みにより大きく変化する。

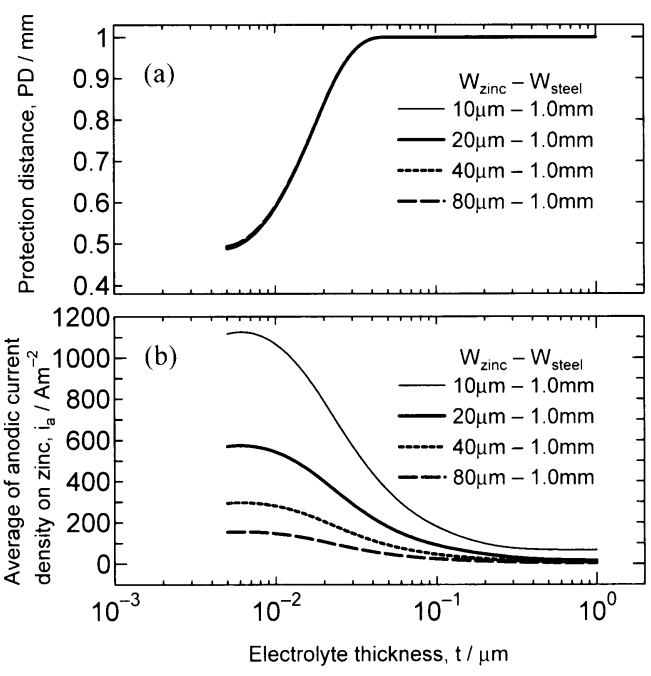

Fig. 17. Plots of (a) the protection distance and (b) the average of anodic current density on the zinc $v s$. electrolyte thickness for different zinc's thicknesses.
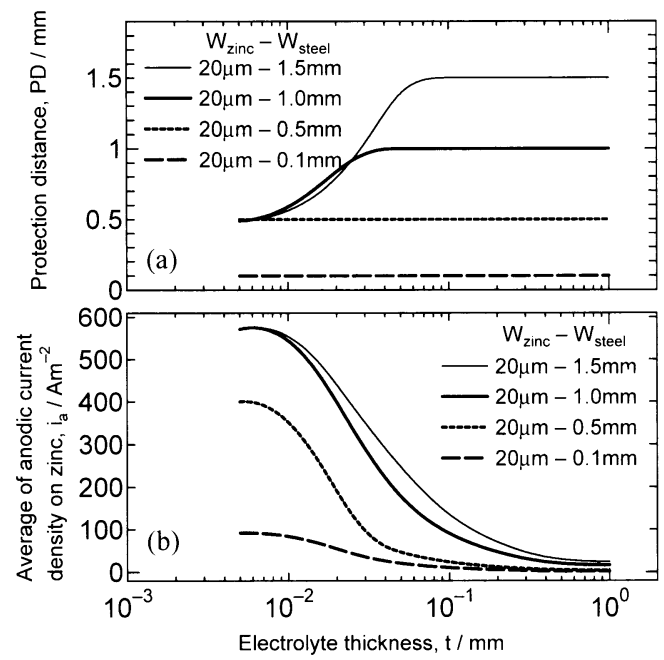

Fig. 18. Plots of (a) the protection distance and (b) the average of anodic current density on the zinc $v s$. the electrolyte thickness for different steel's thicknesses.

\section{4. まとめ}

（1）液膜厚と $\mathrm{NaCl}$ 濃度から分極特性を算出するガルバ ニック腐食の数值解析モデルを開発し, 従来モデルでは困 難であった薄液膜下における解析が可能であることを示し た。但し，本解析モデルの分極特性では考慮されていない 現象が幾つかあり, 分極特性の精度を改善していく必要が ある。

（2）数值解析モデルの妥当性を評価するために実験に よる電位測定結果との比較を行い, その電位差は最大 $0.1 \mathrm{~V}$ 程度であることを確認した。10000 ppm 以上の高 $\mathrm{NaCl}$ 濃度では，数值解析結果と実験結果は比較的良く一 致するが，低 $\mathrm{NaCl}$ 濃度の場合には差が大きくなり，数值 解析結果の電位勾配が実駼結果よりも急峻となる。 
（3）今回開発した数值解析モデルを用いて，鉄一亜鉛 対上における犠牲防食距離の $\mathrm{NaCl}$ 濃度と液膜厚依存性と, 実環境下における覀鉛めっき鋼板端面の犠牲防食距離につ いて検討し，以下の知見を得た。

(a) 防食距離は $\mathrm{NaCl}$ 濃度が高く液膜厚が厚いほど長くな り, $\mathrm{NaCl}$ 濃度が低く膜厚が薄いほど短くなる。また， 犠牲距離も防食距離と同一傾向を示し, その距離は 防食距離の半分程度である。

(b) 鉄部厚みと亜鉛めっき厚みが変化しても犠牲距離と 防食距離は殆ど変化しないが, 亜鉛めっき部の腐食 速度はその影響を大きく受ける。

(c) 数值解析より得た覀鉛めっき鋼板端面の乾燥過程に おける防食距離は， $0.48 \mathrm{~mm}$ 程度であり，暴露実験結 果である $1 \mathrm{~mm}$ 弱という結果4)とオーダ的に一致する。

\section{記 号}

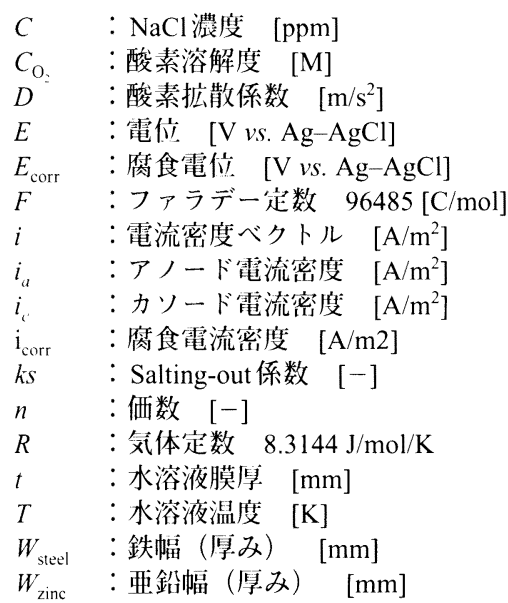

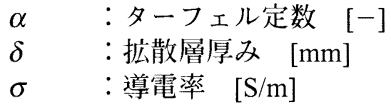

\section{文献}

1）防食技術便覧，腐食防食協会編，日刊工業新聞社，束宗， (1986), 233

2 ) X.G.Zhang and E.M.Valeriote: Corros. Sci., 34 (1993), 1957.

3 ) X.G.Zhang: J. Electrochem. Soc., 143 (1996), 1472.

4 ) X.G.Zhang: Corros. Sci., 56 (2000), 139.

5 ) C.Wagner: J. Electrochem. Soc., 93 (1951), 116.

6 ) E.Kennard and J.T.Waber: J. Electrochem. Soc., 117 (1970), 880

7 ) E.McCafferty: J. Electrochem. Soc., 124 (1977), 1869.

8 ) P.Doig and P.E.J.Flewitt: J. Electrochem. Soc., 126 (1979), 2057.

9 ) R.Strommen: Corrosion' 80, Paper No 241, (1980).

10) M.A.Warne: Corrosion' 85, Paper No. 313, (1985).

11) R.Morris and W. Smyrl: J. Electrochem. Soc., 136 (1989), 3229.

12) R.S.Munn and O.F.Devereux: Corrosion, 47 (1991), 612.

13) R.S.Munn and O.F.Devereux: Corrosion, 47 (1991), 618.

14）青木 繁, 天谷 賢治, 宮坂 松甫: 境界要素法による病食 防食問題の解析，裳華房，東京，(1998).

15) 藤野清次, 張紹良：反復法の数理, 朝弇書战, 東宗, (1996), 24

16) T.Yamazaki, A.Nishikata and T.Tsuru: Zairyo-to-Kankyo, 50 (2001), 30

17) H.Böhni and H.H.Uhlig: J. Electrochem. Soc., 116 (1969), 906.

18）新版 電気化学便覧，電気化学協会編，丸善，東宗，(1964), 120.

19) 新版 電気化学便覧, 電気化学協会編, 丸善, 東京, (1964), 117

20) 新版 電気化学便覧，電気化学協会編，丸善，東京，(1964), 93.

21) W.Lang and R.Zander: Ind. Eng. Chem. Fundam., 25 (1986), 775.

22) K.E.Gubbins and R.D.Walker, Jr.: J. Electrochem. Soc., 112 (1965), 469.

23) E.Tada, K.Sugawara and H.Kaneko: Electrochim. Acta, 49 (2004), 1019.

24) E. Tada, S.Satoh and H.Kaneko: Electrochim. Acta, 49 (2004), 2279. 